\title{
Vermiwash Prepared from Different Combination of Organic Sources to Improve Growth and Yield of Blackgram [Vigna mungo (L.) Hepper] for Organic Agriculture
}

\author{
Deepak Kumar, J.X. Massey, S.K. Sharma, S.L. Mundra, S.K. Yadav
}

10.18805/IJARe.A-5630

\begin{abstract}
Background: Black gram (Vigna mungo) is one of the most important pulse crops grown throughout the country. It is hardy crop and fixes nitrogen in soil. Organic black gram fetch higher price in market i.e., Rs. 175 whereas other receive Rs. 120. Vermiwash, is one among the organic manures which has high potential to increase the crop growth and yield. Thus, present study aims to evaluate the influence of vermiwash prepared from different combination of organic sources on growth and yield of black gram.

Methods: The field experiment was conducted during kharif, 2018 at Organic Farming Unit, Rajasthan College of Agriculture, Udaipur, with nine treatments $\left[T_{1}=\right.$ vermiwash from $100 \%$ cow dung, $T_{2}=$ vermiwash from $100 \%$ buffalo dung, $T_{3}=$ vermiwash from $50 \%$ cow dung $+25 \%$ dry farm waste $+25 \%$ green farm waste, $T_{4}=$ vermiwash from $50 \%$ buffalo dung $+25 \%$ dry farm waste $+25 \%$ green farm waste, $\mathrm{T}_{5}=$ vermiwash from $90 \%$ green waste incubated with $10 \%$ cow dung, $\mathrm{T}_{6}=$ vermiwash from $90 \%$ green waste incubated with $10 \%$ buffalo dung, $T_{7}=$ vermiwash from $90 \%$ dry waste incubated with $10 \%$ cow dung, $T_{8}=$ vermiwash from $90 \%$ dry waste incubated with $10 \%$ buffalo dung and $T_{9}=$ water spray (control)] and were replicated thrice in Randomize Block Design.

Result: The result of experiment revealed that the application of vermiwash from $100 \%$ cow dung significant influence towards growth parameters and yield attributes thus achieved maximum seed yield, haulm yield and B:C ratio (2.3). On the basis of field performance, it may be concluded that the treatment $T_{1}$ (top dressing in two equal split application at the rate of $10 \%$ at initiation of flowering and 15 days after $1^{\text {st }}$ spray) may be recommended as a better organic package of blackgram.
\end{abstract}

Key words: Blackgram, Organic sources, Seed yield, Vermiwash.

\section{INTRODUCTION}

Green Revolution Technologies (GRTs) led to emergence of India as self-sufficient as well as exporting country in terms of food grains but nutritional security remains a cause of concern. India has around a quarter of the world's undernourished population (Sharma et al., 2016). This emphasises the significance of pulses in the Indian population's food and nutrition welfare. The pulses are a valuable source of dietary protein, energy, minerals and vitamins to overcome malnutrition among human beings and their significance in improving soil quality through atmospheric nitrogen fixation, organic matter addition and environment safety. According to $3^{\text {rd }}$ advance estimates of production of major crops for 2019-20, India produced 23.02 million ton of pulses, which is $23.62 \%$ of the world output, with chickpea covering the highest area, followed by pigeonpea, urdbean, mungbean, lentil, pea etc. Among the pulses, blackgram or urdbean [Vigna mungo (L.)] is the fourth most important pulse crop cultivated throughout India for its multipurpose uses as vegetable, pulse, fodder and green manure crop. During 2019-20, India has coverage of 36.44 lakh hectare producing 17.23 lakh tonne of blackgram production. In Rajasthan, it is cultivated in 5.02 lakh hectares with 1.28 lakh tonnes production (Anonymous, 2020-21). It is a good source of protein (25-28\%), oil (1.0 -1.5\%), fibre (3.5 - 4.5\%), ash (4.5 - 5.5\%) and carbohydrates (62 - 65\%) on dry weight basis. It is a good source of minerals, vitamins
Rajasthan College of Agriculture, Maharana Pratap University of Agriculture and Technology, Udaipur-313 001, Rajasthan, India.

Corresponding Author: Deepak Kumar, Rajasthan College of Agriculture, Maharana Pratap University of Agriculture and Technology, Udaipur-313 001, Rajasthan, India.

Email: bhardwaj051238@gmail.com

How to cite this article: Kumar, D., Massey, J.X., Sharma, S.K., Mundra, S.L. and Yadav, S.K. (2021). Vermiwash Prepared from Different Combination of Organic Sources to Improve Growth and Yield of Blackgram [Vigna mungo (L.) Hepper] for Organic Agriculture. Indian Journal of Agricultural Research. DOI: 10.18805/ IJARe.A-5630.

Submitted: 11-06-2020 Accepted: 16-06-2021 Online: 25-08-2021

A, $B_{1}, B_{3}$ and ascorbic acid (Sharma et al. 2011). Being a drought resistant, short duration, photo-insensitivity and dense growing crop, it is suitable for dry land farming and predominantly used in crop intensification and diversification; conservation of natural resources and sustainability of production system. When compared to global average yields, most pulses in India have a lower productivity because of their cultivation on marginal and sub-marginal land with poor soil fertility as well as poor fertilizer and water management. Another major problem that excessive, unbalanced and imprecise chemical fertilisation in the process of attaining higher productivity per unit area, resulted 
in declining soil fertility and productivity, large-scale degradation of soil and water resources, adverse effects on beneficial soil microflora and native bio-diversity and widespread problems associated with the toxic residues of agrochemicals entering into the human and animal food chains (Prasad and Gill, 2009). Modern agriculture has become increasingly unsustainable, scientists go for searching the alternatives and the most well-known alternative to conventional farming is organic farming. It confers sustainability to crop production and also maintains soil nutrient dynamics and safe environment, whereas the crop rotation of cereals with pulses provides long term sustainable farming system and the response of pulses to organic nutrient management is encouraging (Sharma et al. 2017). In organic agriculture, liquid manure plays an important role in boosting crop yields while lowering solid manure uses which are required in bulk amount, having low content of nutrients and very slow rate of nutrients release, whereas liquid manure having high content of total nutrients and quick acting on plants. Vermiwash is nutrients rich liquid manure produced by earthworms, feeding on organic waste material and plants residues. It is a non-toxic and eco-friendly liquid manure which contains macro $(\mathrm{N}, \mathrm{P}, \mathrm{K})$ and micro-plant elements and hormones such as auxin, cytokinine, enzymes, antibiotics, minerals, vitamins and many useful microbes like heterotrophic bacteria, fungi etc. (Edwards and Burrows, 1988; Buckerfield et al.,1999; Tripathi and Bhardwaj,2004; Zambare et al., 2008). The quality of vermiwash produced by earthworms depends on different vermicomposts used that are prepared from different farm and animal wastes (Rai and Bansiwal, 2008; Nath and Singh, 2012).

Hence, the present investigation was undertaken to study the effect of vermiwash prepared from different combination of organic sources on growth and yield of blackgram.

\section{MATERIAL AND METHODS}

The experiment was carried out at Organic Farming Unit, Rajasthan College of Agriculture, Udaipur, situated at SouthEastern part of Rajasthan at a height of $582.17 \mathrm{~m}$ above mean sea level and at $24^{\circ} 35^{\prime} \mathrm{N}$ latitude and $73^{\circ} 42^{\prime} \mathrm{E}$ longitude to study the effect of vermiwash on blackgram during kharif, 2018.During the crop growing season, the average maximum and minimum temperature ranged between 27.9 to $32.2^{\circ} \mathrm{C}$ and 21.0 to $24.0^{\circ} \mathrm{C}$, respectively. The average rainfall is $488.8 \mathrm{~mm}, 75 \%$ of which is received from June to September. The texture of experimental soil was clay loam, slightly alkaline in reaction, low in available nitrogen, medium in available phosphorus and potassium as well as high in calcium carbonate. The experiment was laid down randomised block design with three replication comprising nine treatments i.e. ( $T_{1}=$ vermiwash from $100 \%$ cow dung, $\mathrm{T}_{2}=$ vermiwash from $100 \%$ buffalo dung, $\mathrm{T}_{3}=$ vermiwash from $50 \%$ cow dung $+25 \%$ dry farm waste + $25 \%$ green farm waste, $\mathrm{T}_{4}=$ vermiwash from $50 \%$ buffalo dung $+25 \%$ dry farm waste $+25 \%$ green farm waste, $T_{5}=$ vermiwash from $90 \%$ green waste incubated with $10 \%$ cow dung, $\mathrm{T}_{6}=$ vermiwash from $90 \%$ green waste incubated with $10 \%$ buffalo dung, $T_{7}=$ vermiwash from $90 \%$ dry waste incubated with $10 \%$ cow dung and $\mathrm{T}_{8}=$ vermiwash from $90 \%$ dry waste incubated with $10 \%$ buffalo dung and $\mathrm{T}_{9}=$ control). Vermiwash was prepared from different organic sources i.e., cow dung, buffalo dung, green and dry farm waste, by using earthen pot method in which an earthen pot of 10 liter capacity with a hole at the base was taken and a rubber pipe was fixed in the hole. First of all, a thin layer of coarse sand is laid in the pot; above the sandy layer, $15-20 \mathrm{~cm}$ thick layer of 15- 20 days old cow dung was placed which followed by $15 \mathrm{~cm}$ thick layer of farm green or dry waste. The layers of cow dung and farm waste was repeated until the pot was filled. Water is sprinkled in between the layers to provide moisture. About 1000 epigenic earthworms (Eisenia foetida) mixed with the feed. One more pot filled with water is placed above it so that drop wise water enters into the vermicompost pot. Third pot was placed below it. Assembly of these three earthen pots was hanged at a shady place. The vermiwash was collected in the third pot in between 30-35 days of period and use as foliar spray in dilution with water. Each plot had an area of $4.0 \mathrm{~m} \times 3.0 \mathrm{~m}$. The treated seeds of black gram with rhizobium culture were sown with a spacing of $30 \mathrm{~cm} \times 10 \mathrm{~cm}$. The crop was fertilized as basal dose in form of $4 \mathrm{t}$ of FYM ha ${ }^{-1}$, rest was applied through vermiwash liquid manures as top dressing in 2 equal splits at the rate of $10 \%$ at the initiation of flowering and 15 days after $1^{\text {st }}$ spray to all treatments except control. Necessary field operations like irrigation, weeding and disease-pest management were done as and when needed. Pods were harvested by manually picking when pods turn black/dark brown. Growth parameters viz. plant height, dry matter accumulation plant $^{-1}$ was recorded at45 and 60days after sowing (DAS). Yield components namely number of pods plant ${ }^{-1}$, number of seeds pod $^{-1}$, test weight and seed yield and haulm yield were recorded at harvest. To find out the more profitable treatment, economics of different treatments were worked out in terms of $\mathrm{B}: \mathrm{C}$ ratio on the basis of prevailing market rate so that the remunerative treatment could be recommended.

The data was subjected to statistical analysis of variance as outline by Panse and Sukhatme (1985).

\section{RESULTS AND DISCUSSION}

All the treatments except control significantly influenced growth parameters of blackgram. Plant height and dry matter accumulation increased consistently with the advancement of crop growth stages i.e., 45to 60 DAS (Table 1). Among the different treatments, application of vermiwash from $100 \%$ cow dung recorded significantly higher plant height (31.3 and $39 \mathrm{~cm}$ ) and dry matter production (3.5 and $6.83 \mathrm{~g} \mathrm{plant}^{-1}$ ) at 45 and 60 DAS, respectively. This might be due to influence of vermiwash as a potential source of macro and micronutrients, enzymes, vitamin and growth hormones like gibberellins etc. that have created stimuli in the plant system 
Vermiwash Prepared from Different Combination of Organic Sources to Improve Growth and Yield of Blackgram [Vigna mungo...

and increased the production of growth regulators in the cell which stimulated the growth and development of plant. Similar results were obtained by Maya and Satish, 2015. It is an established fact that foliar application of vermiwash in blackgram crop supplies almost all the essential plant nutrients for the growth and development of plants. The present findings were accordance with the earlier reports of
Subha et al., 2003; Kauri and Kauri, 2017; and Rekha et al., 2013. Blackgram yield potential is determined by yield components and the values of yield components were in accordance with that of growth parameters. Dry matter accumulation supported the seed yield and have positive correlation with seed yield (Fig 1). There was significant influence on yield attributes and yield of blackgram grown

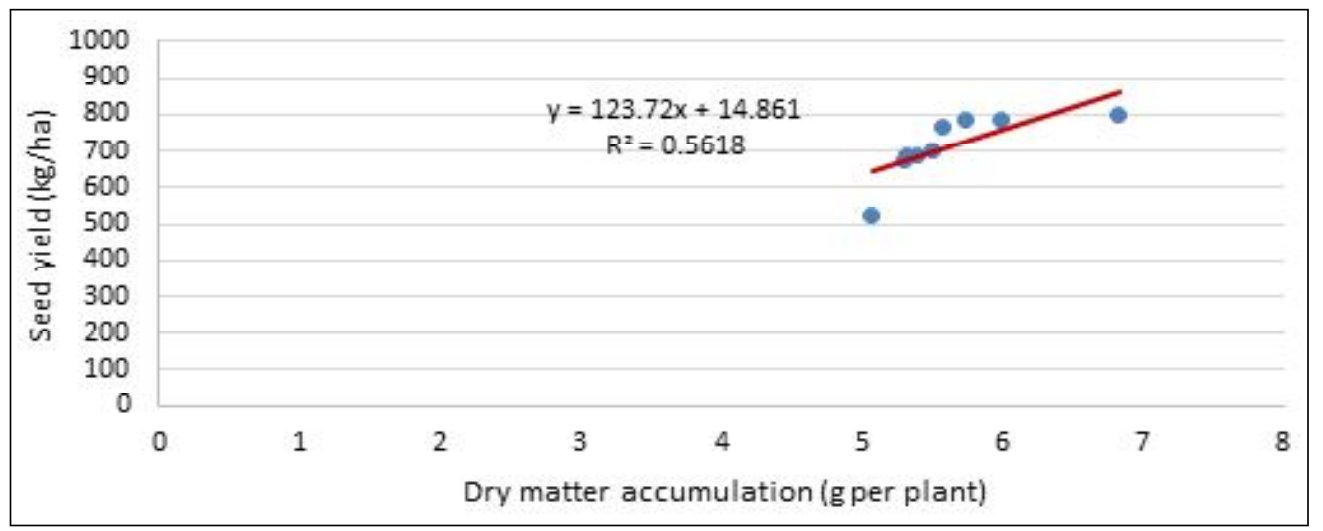

Fig 1: Correlation between dry matter accumulation $\left(\mathrm{g} \mathrm{plant}^{-1}\right)$ and seed yield $\left(\mathrm{kg} \mathrm{ha}^{-1}\right)$.

Table 1: Effect of vermiwash from different organic sources on growth parameters of blackgram.

\begin{tabular}{|c|c|c|c|c|}
\hline \multirow[t]{2}{*}{ Treatments } & \multicolumn{2}{|c|}{$\begin{array}{l}\text { Plant height } \\
\text { (cm) }\end{array}$} & \multicolumn{2}{|c|}{$\begin{array}{l}\text { Dry matter } \\
\text { accumulation } \\
\quad\left(\text { g plant }^{-1}\right)\end{array}$} \\
\hline & 45 DAS & 60 DAS & 45 DAS & $60 \mathrm{DAS}$ \\
\hline$T_{1}$. Vermiwash from $100 \%$ cow dung & 31.3 & 39.0 & 3.50 & 6.83 \\
\hline $\mathrm{T}_{2 .}$ Vermiwash from $100 \%$ buffalo dung & 28.3 & 35.7 & 3.33 & 5.73 \\
\hline$T_{3}$ Vermiwash from $50 \%$ cow dung $+25 \%$ dry farm waste $+25 \%$ green farm waste & 29.3 & 36.0 & 3.45 & 6.00 \\
\hline$T_{4}$. Vermiwash from $50 \%$ buffalo dung $+25 \%$ dry farm waste $+25 \%$ green farm waste & 27.3 & 35.0 & 3.30 & 5.57 \\
\hline$T_{5}$ Vermiwash from $90 \%$ green waste incubated with $10 \%$ cow dung & 27.3 & 34.7 & 3.30 & 5.50 \\
\hline $\mathrm{T}_{6}$. Vermiwash from $90 \%$ green waste incubated with $10 \%$ buffalo dung & 27.0 & 34.3 & 3.28 & 5.40 \\
\hline$T_{7}$ Vermiwash from $90 \%$ dry waste incubated with $10 \%$ cow dung & 26.7 & 33.3 & 3.27 & 5.33 \\
\hline $\mathrm{T}_{8 .}$ Vermiwash from $90 \%$ dry waste incubated with $10 \%$ buffalo dung & 26.3 & 32.3 & 3.22 & 5.30 \\
\hline $\mathrm{T}_{9}$. Water spray (Control) & 25.3 & 31.7 & 3.10 & 5.07 \\
\hline S.Em \pm & 0.4 & 0.6 & 0.05 & 0.14 \\
\hline$C D(P=0.05)$ & 1.1 & 1.8 & 0.16 & 0.42 \\
\hline
\end{tabular}

Table 2: Effect of vermiwash from different organic sources on yield attributes of blackgram.

\begin{tabular}{|c|c|c|c|}
\hline \multirow[b]{2}{*}{ Treatments } & \multicolumn{3}{|c|}{ Yield Attributes } \\
\hline & $\begin{array}{c}\text { No. of } \\
\text { pods plant }^{-1}\end{array}$ & $\begin{array}{c}\text { No. of } \\
\text { seeds pod }{ }^{-1}\end{array}$ & $\begin{array}{c}\text { Test weight } \\
\text { (g) }\end{array}$ \\
\hline $\mathrm{T}_{1}$. Vermiwash from $100 \%$ cow dung & 24.67 & 6.00 & 35.88 \\
\hline$T_{2}$. Vermiwash from $100 \%$ buffalo dung & 23.00 & 5.67 & 34.93 \\
\hline$T_{3}$ Vermiwash from $50 \%$ cow dung $+25 \%$ dry farm waste $+25 \%$ green farm waste & 23.33 & 5.73 & 35.23 \\
\hline $\mathrm{T}_{4}$. Vermiwash from $50 \%$ buffalo dung $+25 \%$ dry farm waste $+25 \%$ green farm waste & 22.33 & 5.61 & 34.34 \\
\hline $\mathrm{T}_{5}$ Vermiwash from $90 \%$ green waste incubated with $10 \%$ cow dung & 22.00 & 5.33 & 34.11 \\
\hline $\mathrm{T}_{6 .}$ Vermiwash from $90 \%$ green waste incubated with $10 \%$ buffalo dung & 21.67 & 5.24 & 33.75 \\
\hline $\mathrm{T}_{7}$. Vermiwash from $90 \%$ dry waste incubated with $10 \%$ cow dung & 21.67 & 5.11 & 33.23 \\
\hline$T_{8 .}$ Vermiwash from $90 \%$ dry waste incubated with $10 \%$ buffalo dung & 21.33 & 5.00 & 32.83 \\
\hline$T_{9}$. Water spray (Control) & 19.00 & 4.60 & 32.24 \\
\hline S.Em \pm & 0.64 & 0.24 & 0.071 \\
\hline $\mathrm{CD}(\mathrm{P}=0.05)$ & 1.93 & 0.72 & 2.1 \\
\hline
\end{tabular}


Vermiwash Prepared from Different Combination of Organic Sources to Improve Growth and Yield of Blackgram [Vigna mungo...

Table 3: Effect of vermiwash from different organic sources on yield and economics of blackgram.

\begin{tabular}{|c|c|c|c|}
\hline Treatments & $\begin{array}{l}\text { Seed yield } \\
\left(\mathrm{kg} \mathrm{ha}^{-1}\right)\end{array}$ & $\begin{array}{l}\text { Haulm yield } \\
\qquad\left(\mathrm{kg} \mathrm{ha}^{-1}\right)\end{array}$ & $\begin{array}{l}\text { B C } \\
\text { ratio }\end{array}$ \\
\hline $\mathrm{T}_{1}$. Vermiwash from $100 \%$ cow dung & 800 & 1743 & 2.33 \\
\hline $\mathrm{T}_{2 .}$ Vermiwash from $100 \%$ buffalo dung & 784 & 1704 & 2.26 \\
\hline$T_{3 .}$ Vermiwash from $50 \%$ cow dung $+25 \%$ dry farm waste $+25 \%$ green farm waste & 786 & 1712 & 2.25 \\
\hline $\mathrm{T}_{4}$ Vermiwash from $50 \%$ buffalo dung $+25 \%$ dry farm waste $+25 \%$ green farm waste & 765 & 1663 & 2.16 \\
\hline $\mathrm{T}_{5}$. Vermiwash from $90 \%$ green waste incubated with $10 \%$ cow dung & 699 & 1521 & 1.87 \\
\hline $\mathrm{T}_{6}$. Vermiwash from $90 \%$ green waste incubated with $10 \%$ buffalo dung & 691 & 1506 & 1.84 \\
\hline $\mathrm{T}_{7}$. Vermiwash from $90 \%$ dry waste incubated with $10 \%$ cow dung & 685 & 1492 & 1.81 \\
\hline $\mathrm{T}_{8}$. Vermiwash from $90 \%$ dry waste incubated with $10 \%$ buffalo dung & 676 & 1472 & 1.78 \\
\hline $\mathrm{T}_{9}$. Water spray (Control) & 524 & 1168 & 1.33 \\
\hline S.Em \pm & 31.96 & 69.65 & 0.09 \\
\hline$\underline{C D}(P=0.05)$ & 95.82 & 208.82 & 0.26 \\
\hline
\end{tabular}

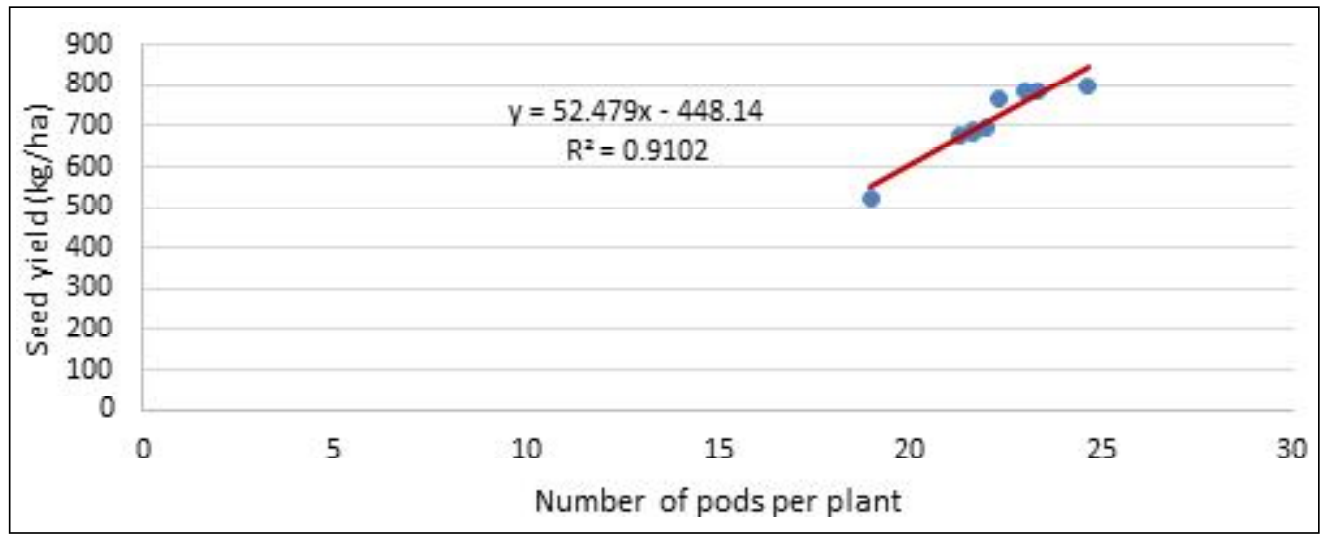

Fig 2: Correlation between number of pods plant ${ }^{-1}$ and seed yield $\left(\mathrm{kg} \mathrm{ha}^{-1}\right)$.

under different vermiwash treatments (Table 2). Among the different treatments, application of vermiwash from $100 \%$ cow dung registered higher number of pods plant $^{-1}(24.67)$, seeds pod $^{-1}(6)$ and test weight (35.88) which found to be at par with vermiwash from $50 \%$ cow dung $+25 \%$ dry farm waste $+25 \%$ green farm waste, vermiwash from $100 \%$ buffalo dung, vermiwash from $50 \%$ buffalo dung $+25 \%$ dry farm waste $+25 \%$ green farm waste. The positive impact of availability of plant nutrients, enzymes and growth hormones in balanced form might have induced cell division, cell wall expansion, high meristematic activity, photosynthetic efficiency and assimilate partitioning from source to sink that increased yield attributes and help to produce healthy seed. The result was in agreement with the findings of Jadhav et al. (2014). Among the treatments, the application of vermiwash from $100 \%$ cow dung significantly registered higher seed yield (800 $\left.\mathrm{kg} \mathrm{ha}^{-1}\right)$ and haulm yield $(1743 \mathrm{~kg} \mathrm{ha-}$ $\left.{ }^{1}\right)$ of blackgram on rest of treatments (Table 3). However, it was at par with vermiwash from $50 \%$ cow dung $+25 \%$ dry farm waste $+25 \%$ green farm waste, vermiwash from $100 \%$ buffalo dung and vermiwash from $50 \%$ buffalo dung $+25 \%$ dry farm waste $+25 \%$ green farm waste of blackgram, respectively. Crop yield is the complex function of physiological processes and biochemical activities which modify plant anatomy and morphology of the growing plants. This might be due to favourable effect of vermiwash on vegetative and reproductive growth viz., pods plant ${ }^{-1}$, seeds pod $^{-1}$ and test weight, which were the important yield attributes having significant positive correlation with seed and haulm yield (Fig 2). The similar results were also reported by Venkataramana el at. (2007); Hatti et al. (2010); Ramesh et al. (2012); Sundarasu et al. (2014); Bhardwaj and Sharma (2016) and Devasinghe and Kularathna (2016). It is evident from the results that the vermiwash prepared from different combination of organic sources considered in treatments had significant effect on growth and productivity of blackgram. Similar observation of vermiwash prepared from different vermicompost were reported by Rai and Bansiwal (2008); and Nath and Singh (2012).

Small and marginal farmers are more likely to consider a research result if it is economically viable. In the present study, the economics of blackgram cultivation was influenced by different vermiwash treatment (Table 3). The B:C ratio higher with the application of vermiwash from $100 \%$ cow dung (2.3) which was at par with the application of vermiwash from $100 \%$ buffalo dung, vermiwash from $50 \%$ cow dung + 
$25 \%$ dry farm waste $+25 \%$ green farm waste and vermiwash from $50 \%$ buffalo dung $+25 \%$ dry farm waste $+25 \%$ green farm waste, respectively.

\section{CONCLUSION}

Considering the results of the experiment, it may be advocated that vermiwash prepared from different combination of organic sources have significant effect on growth and yield characteristics of blackgram under organic farming; and the treatment vermiwash from 100\% cow dung (top dressing in two equal split application at the of $10 \%$ at initiation of flowering and 15 days after $1^{\text {st }}$ spray) may be recommended as a better organic practice of blackgram followed by vermiwash from $50 \%$ cow dung $+25 \%$ dry farm waste $+25 \%$ green farm waste, vermiwash from $100 \%$ buffalo dung and vermiwash from $50 \%$ buffalo dung $+25 \%$ dry farm waste $+25 \%$ green farm waste, respectively.

\section{REFERENCES}

Anonymous (2020). Department of agriculture and farmer welfare. https://agricoop.nic.in/en.

Bhardwaj, P. and Sharma, R.K. (2016). Effect of vermiwash and vermicompost on the growth and productivity of greengram. Journal of Chemical, Biological and Physical Sciences. 6(4): 1381-1388.

Buckerfield, J.C., Flavel, T., Lee, K.E. and Webster, K.A. (1999). Vermicompost soil and liquid form as plant growth promoter. Pedobiologia. 42: 753-759.

Devasinghe, U. and Kularathna, L. (2016). Effect of effective microorganisms and vermiwash on yield and quality of lettuce (Lactuca sativa L.) in hydroponic cultivation. International Journal of Chemical, Environmental and Biological Science. 4(1): 78-81.

Edwards, C.A. and Burrows, I. (1988). The potential of earthworm compost as plant growth media. In: [Edwards, C.A. and Neuhauser, E.F. Eds.] Earthworm in waste and environmental management. SPB Academic Publishers, The Netherland Pp. 21-32.

Hatti, S.S., Londonkar, R.L., Patil, S.B., Gangawane, A.K. and Patil, C.S. (2010). Effect of Perionyx excavatus vermiwash on the growth of plants Vigna mungo, Vigna radiata and Sesamum indicum. Journal of Crop Science. 1(1): 1-5.

Jadhav, P.B., Kireeti, A., Patil, N.B., Dekhane, S.S. and Patel, D.J. (2014). Effect of different levels of vermiwash spray on growth and yield of radish $\mathrm{cv}$. local variety. The Asian Journal of Horticulture. 9(2): 449-452.

Kauri, M. and Kauri, D.P. (2017). Vermiwash: An effective nutritive boon to foliage and crops. Journal of Applied and Natural Science. 9(3): 1608-1611.

Maya, M.J. and Satish, A.B. (2015). Influence of vermiwash on germination and growth parameters of seedlings of greengram (Vigna radiata L.) and blackgram (Vigna mungo). International Journal of Current Microbiology and Applied Sciences. 4(9): 635-643.
Nath, G. and Singh, K. (2012). Effect of vermiwash of different vermicomposts on the kharif crops. Journal of Central European Agriculture. 13(2): 379-402.

Panse, V.G. and Sukhatme, V.P. (1985). Statistical methods for agricultural workers. Indian Council of Agricultural Research, New Delhi.

Prasad, K. and Gill M.S. (2009). Development and strategies perspective for organic farming in India. Indian Journal of Agronomy. 54(2): 86-192.

Rai, N. and Bansiwal (2008). Vermiwash: An excellent source of nutrition for plant growth. Electronic Journal of Environmental Sciences. 1: 19-21.

Ramesh, S., Sudhakar, P. and Elankavi, S. (2012). Effect of foliar nutrition on growth, yield attributes and yield of rice fallow blackgram [Vigna mungo]. International Journal of Development Research. 3(2): 5-7.

Rekha, G.S., Valivittan, K. and Kaleena, P.K. (2013). Studies on the influence of vermicompost and vermiwash on the growth and productivity of black gram (vigna mungo). Advances in Biological Research. 7(4): 114-121.

Sharma, O.P., Bambawale, O.M., Gopali, J.B., Bhagat, S., Yelshetty, S., Singh, S.K., Anand, R. and Singh, O.P. (2011). Field guide mungbean and urdbean, National Centre for Integrated Pest Management, New Delhi, India. p. 40.

Sharma, P., Dwivedi, S. and Singh, D. (2016). Global poverty, hunger and malnutrition: a situational analysis. (In) Biofortification of Food Crops, [Singh, U., Praharaj, C.S., Singh, S.S. and Singh, N.P. (Eds)]. Springer,New Delhi. pp. 19-30.

Sharma, S.K., Choudhary, R., Trivedi, A., Choudhary, R.S. and Yadav, S.K. (2017). Response of organic nutrient management practices on soil properties and productivity of chickpea (Cicer arietinum L.). International Journal of Bio-resource and Stress Management. 8(2): 196-200.

Subha, R., Ganesh, P., Mohan, G., Saleem, S. and Vijayalakshmi, G. (2003). Effect of vermiwash on the growth of black gram Vigna mungo. Geobios. 30(1): 77-79.

Sundararasu, K. and Jeyasankar, A. (2014). Effect of vermiwash on growth and yield of brinjal (Solanum melongena). Asian Journal of Science and Technology. 5(3): 171-173.

Thipathi, G. and Bhardwaj, P. (2004). Comparative studies on biomess production, life cycles and composting efficiency of Eisenia foteida (Savigny) and Lampitomauritii (Kinberg). Bioresources Technology. 92(3): 275-283.

Venkataramana, P., Murthy, B., Narasimha, R., Krishna, J.V. and Kamble, C.K. (2009). Efficacy of foliar sprays of vermiwash and cow dung wash on biochemical and yield attributes and yield of mulberry (Morus alba L.). Karnataka Journal of Agriculture Science. 22(4): 921-923.

Zambare, V.P., Padul, M.V., Yadav, A.A. and Shete, T.B. (2008). Vermiwash: Biochemical and microbiological approach as ecofriendly soil conditioner. Journal of Agriculture and Biology Science. 3(4): 1-5. 